\title{
Phosphodiesterase Found in Young Wheat Roots
}

\author{
By Fumio Ibuki, Akiji Aokr* and Setsuro Matsushita \\ The Research Institute for Food Science, Kyoto University and \\ *Kokoku Rayon Pulp Co., Lid. \\ Received July 1, 1963
}

\begin{abstract}
Phosphodiesterase has been found in the particulate and soluble fractions from young wheat roots. The intracellular distribution of this enzyme was studied by using RNA, oligo DNA and DNPP as the substrates. When oligo DNA was used, 50 to 60 per cent of PPDase activity was found in the soluble fraction and 30 to 40 per cent in the microsomal fraction. Besides magnesium ion, calcium, cobalt, manganese and nickel ions were effective for its activity. The $\mathrm{pH}$ optimum of the enzyme was found at 6.0. This PPDase produced 5'-nucleotides from RNA at $\mathrm{pH} 6.9$ on addition of magnesium chloride.
\end{abstract}

\section{INTRODUCTION}

Previous communications ${ }^{1 \sim 3)}$ from our laboratory reported that the microsomes from young wheat roots and pea seedlings contained RNases which were inactivated by EDTA and activated by magnesium ion. Recently, similar enzymes were found in cytoplasmic particles from apple leaves by Kessler et al. ${ }^{4}$, and in corn seedlings by Wilson $^{5}$. Preceling communication ${ }^{6}$ reported that the RNase inactivated by EDTA seemed to be the PPDase present in particulate fractions of wheat roots and this PPDase produced 5'-nucleotides from RNA.

In the present paper, it is described that PPDase activities in wheat seedlings were found not only in particulate fractions but also in the soluble fraction. And the basic

\footnotetext{
The abbreviations used are: RNase, ribonuclease; DNase, deoxyribonuclease; PPDase, phosphodiesterase; RNA, ribonucleic acid; DNA deoxyribonucleic acid; DNPP, bis ( $p$-nitrophenyl) phosphate; GMP, AMP GMP and UMP, cytidylic acid, adenylic acid, guanylic acid and uridylic acid; Tris, tris (hydroxymethyl) aminomethane; EDTA, ethylenediaminetetraacetic acid (disodum salt).

1) S. Matsushita, Mem. Res. Inst. Food Sci., Kyoto Univ., 17, 29 (1959).

2) S. Matsushita, ibid., 18, 8 (1959).

3) S. Marsushita and F. Ibuki, Biochim. Biophys. Acta, 40, 358 (1960)

4) B. Kessler and N. Engelberg, ibid., 55, 70 (1962).

5) C.M. Wilson, ibid, 68, 177 (1963).

6) F. Mouki, A. Aoki and S. Matsushita, This Journal, 27, 316 (1963)
}

properties of the enzyme are described.

\section{MATERIALS AND METHODS}

\section{Preparation of Subcellular Fractions.}

The wheat roots prepared from wheat seedlings germinated for 7 to 10 days in the dark at $20^{\circ} \mathrm{C}$ were ground in a mechanical grinder with equal volume of $0.5 \mathrm{~m}$ sucrose solution. The mixture was filtered through cotton cloth and the filtrate fractionated by differential centrifugation. After centrifugation of the filtrate at $600 \times \mathrm{g}$ for twenty minutes, cell debris and rucleus fractions were obtained as a precipitate The supernatant was centrifuged at $10,000 \times \mathrm{g}$ for thirty minutes, and mitochondrial sediment was obtained. The supernatant was further centrifuged at $100,000 \times \mathrm{g}$ for two hours to give a sediment of microsomes and a final supernatant. All operations were carried out under $5^{\circ} \mathrm{C}$. Each particulate fraction was stored as the suspension in $0.25 \mathrm{M}$ sucrose solution wihch was diluted with water on experiments. The particulate suspensions were used to investigate the cellular distribution of the PPDase activity without dialysis against water since 30 to 40 per cent of the activity in each fraction was lost by dialysis. The amount of protein was calculated from the total nitrogen determined by the micro-Kjeldahl method.

\section{Preparation of Substrates.}

a) RNA. Yeast RNA purchased from Nutritional Biochemicals Corporation was purified by the method 


\section{of Chantrenne?}

b) Oligo DNA. Oligo DNA was prepared by the method of Butlex ${ }^{\text {s) }}$ and Chargaf( ${ }^{p)}$. Five hundred $\mathrm{mg}$ of sperm DNA was incubated with $2 \mathrm{mg}$ of crystalline DNase in $30 \mathrm{ml}$ of $0.003 \mathrm{M} \mathrm{MgSO}_{4}$ of $\mathrm{pH} 6.5$ at $37^{\circ} \mathrm{C}$ for about forty hours. After the whole phosphorus of DNA became soluble in 10 per cent trichloroacetic acid, the reaction mixture was deproteinized with chloroform-amylalcohol (10:1). Brownish clear water layer was concentrated in vacuo and used as the substrate. This solution contained $2.1 \mathrm{mg}$ phosphorus of DNA per $\mathrm{ml}$, and the concentration of $\mathrm{MgSO}_{4}$ was $4.5 \times 10^{-3}$ ir. About $10 \mathrm{per}$ cent of the initial substrate was soluble in the uranyl reagent $(0.25$ per cent uranium acetate in $0.2 \mathrm{~N}$ perchloric acid). Sperm DNA and crystalline DNase used were obtained from Nutritional Biochemicals Corporation.

c) DNPP. DNPP was synthesized as Ca-salt by the method of Laskowskins.

\section{Measurement of Enzyme Activities.}

a) RNase Activity. Standard assay condition was as follows: The reaction mixture, total volume of $2 \mathrm{ml}$, containing $5 \mathrm{mg}$ of yeast RNA, $20 \mu$ moles of $\mathrm{MgCl}_{2}$ (or EDTA), $200 \mu$ moles of acetate buffer $(\mathrm{pH}$ 6.0 ) and enzyme, was incubated at $37^{\circ} \mathrm{C}$ for thirty minutes. The reaction was stopped by the addition of $2 \mathrm{ml}$ uranyl reagent. The suspension was filtered, the filtrate was diluted to eleven times and the extinction of the filtrate was measured at $260 \mathrm{~m} \mu$. A value of 0.350 was used as the extinction at $260 \mathrm{~m}_{\mu}$ through $1 \mathrm{~cm}$ light path given by $1 \mu \mathrm{g}$ phosphorus of RNA per $m^{11)}$. One unit of the enzyme was defined as the amount of enzyme which gave the formation of $0.2 \mu \mathrm{g}$ of acid soluble phosphorus per minute in the reaction mixture.

b) PPDase Activity. When oligo DNA was used as the substrate, the standard assay condition was as follows: The reaction mixture, total volume of $2 \mathrm{ml}$, containing $0.1 \mathrm{ml}$ of oligo DNA, $20 \mu$ moles of $\mathrm{MgCl}_{2}$ (or EDTA), $200 \mu$ moles of acetate buffer (pH 6.0) and enzyme was incubated at $37^{\circ} \mathrm{C}$ for one hour. The boluble fragments were determined spectrophotometrically in a similar manner with the measurement

7) H. Chantrenne, Bull. Soc. Chim. Belg., 55, 5 (1946).

8) J.A. Little and G.C. Butler, J. Biol. Chem., 188, 695 (195I).

9) G. Brawerman and E. Chargaff, ibid., 210,445 (1954)

10) M. Privat de Garilhe and M. Laskowski, Biochim. Biophys. Acta, 18, $370(1955)$.

11) M. Ogur and G. Rosen, Arch. Biochem. Biophys., 25, 262 (1950). of RNase activity. The activity was measured in a range of concentration of enzyme where the amount of soluble phosphorus formed is proportional to the concentration of enzyme used $(0.2$ to 0.5 as the reading of the optical density). A value of 0.283 was used as the extinction at $260 \mathrm{~m}_{\mu}$ through $\mathrm{I} \mathrm{cm}$ light path given by $1 \mu \mathrm{g}$ phosphorus of DNA per $\mathrm{ml}^{11)}$ One unit of the enzyme was defined as the amount of enzyme which catalyzed the formation of $2 \mu$ moles of acid soluble phosphorus per hour in the reaction mixture.

When DNPP was used as the substrate, the method was as follows: The reaction mixture containing in a total volume of $4 \mathrm{ml}, 2 \mu$ moles of Ca (DNPP) .40 $\mu$ moles of $\mathrm{MgCl}_{2}$ (or EDTA), $400 \mu$ moles of acetate buffer ( $\mathrm{pH}$ 6.0) and enzyme was incubated at $37^{\circ} \mathrm{C}$ for twenty minutes. The reaction was stopped by the addition of $1 \mathrm{ml}$ of $1 \mathrm{~N} \mathrm{NaOH}$ and the precipitate formed was removed by centrifugation. Optical density of the supernatant was measured at $420 \mathrm{~m} \mu^{122}$. $p$-Nitrophenylphosphate formed from DNPP by PPDase was further hydrolyzed into $p$-nitrophenol and orthophosphate by phosphomonoesterase which existed in the enzyme fraction. Therefore, the amount of orthophosphate formed in the reaction mixture was also determined by the method of Allen ${ }^{133}$, and then true absorption at $420 \mathrm{~m}_{\mu}$ of the $p$-nitrophenol formed only by PPDase was calculated by the method described by Ogata et al. ${ }^{10}$ The value of 13,500 was used as the molar extinction coefficient of $p$-nitrophenol at $420 \mathrm{~m} \mu$ in alkali. One unit of the enzyme was defined as the amount of enzyme which catalyzed the formation of $4 \mu$ moles of $p$-nitrophenol per hour in the reaction mixture. EDTA was adjusted to each pH through all experiments.

\section{Column Chromatography.}

Column chromatography was carried out according to the method of Potter ${ }^{1 / 4)}$. Dowex $1 \times 2$ (formate form, 200 to 400 mesh) in a $20 \mathrm{~cm} \times 1 \mathrm{~cm}$ column and a $250 \mathrm{ml}$ mixing volume was used. The neutralized acid soluble fraction was applied on a column. After column had been washed with water to remove bases and nucleosides, nucleotides were eluted by gradient method with $4 \mathrm{~N}$ formic acid.

12) Y. Nakao and K. Ogata, This Journal, 27, 291 (1963).

13) R.J. Allen, Biochem. J., 34, 858 (1940).

14) R.B. Hurlbert, H. Schmitz, A.F. Brumm and V.R. Potter, J. Biol. Chem., 209, 23 (1954). 
Thin Layer Chromatography.

Fifteen grams of MN $300 \mathrm{G}$ cellulose powder purchased from Macherey, Nagel and Co., was blended with $90 \mathrm{ml}$ of water and the use of spreading device gave 5 plates of $200 \times 200 \mathrm{~mm}$ with a $275 \mu$ layer. After drying at $105^{\circ} \mathrm{C}$ for ten minutes, the plates were used for chromatography. Isobutyric acid-1 M $\mathrm{NH}_{1} \mathrm{OH}-0.1 \mathrm{n}$ EDTA $(100: 60: 1.6)$ solvent system ${ }^{15)}$ was used for developing. After developing for two hours at room temperature, the plates were sprayed with the solution of 0.01 per cent fuorescein in $0.5 \mathrm{~N}$ $\mathrm{NH}_{4} \mathrm{OH}$, and photographed in a dark room with ultraviolet light.

\section{RESULTS}

Hydrolysis of RNA.

As shown in Table $I$, the hydrolytic activities of particulate fractions for RNA were all activated by the addition of magnesium chloride and inactivated by EDTA. However, with the supernatant fraction, such phenomenon was not observed. These results might be considered to be caused by the existence of both RNase which did not require metal ions for its activity, and nucleases which required metal ions for their activities.

TABLE I. HYDROLYSIS OF RNA BY SUBCELlULAR FRACTIONS FROM YOUNG WHEAT ROOTS

$\begin{array}{crcrl}\text { Fraction } & \text { None } & \begin{array}{c}\text { Total units } \\ \text { addition } \\ \mathrm{MgCl}_{2}\end{array} & \text { EDTA } & \begin{array}{c}\text { Total } \\ \text { protein } \\ (\mathrm{mg})\end{array} \\ 600 \mathrm{~g} & 2,980 & 4,180 & 1,980 & 101 \\ 10,000 \mathrm{~g} & 10,800 & 15,600 & 4,910 & 196 \\ 100,000 \mathrm{~g} & 21,400 & 30,800 & 12,500 & 135 \\ \text { Supernatant } & 36,200 & 29,300 & 27,200 & 561 \\ 290 \mathrm{~g} \text { of young wheat roots was used for preparation. }\end{array}$

\section{Hydrolysis of Oligo DNA and DNPP.}

PPDase activity in each fraction was measured by using oligo DNA and DNPP which are thought to be specific substrates for PPDase, and the results are shown in Table II. PPDase activity was mainly found in the microsomal and supernatant fraction. When

15) M. Smith, G.I. Drummond and H.G. Khorana, J. Am. Chem. Soc, 83,698 (1961).

\begin{tabular}{|c|c|c|c|c|c|}
\hline \multirow{3}{*}{ Fraction } & \multicolumn{4}{|c|}{ Total units } & \multirow{3}{*}{$\begin{array}{l}\text { Total } \\
\text { protein } \\
\text { (mg) }\end{array}$} \\
\hline & \multirow{2}{*}{$\frac{\text { Oligo }}{\mathrm{MgCl}_{2}}$} & \multirow{2}{*}{$\frac{\text { DNA }}{\text { EDTA }}$} & \multicolumn{2}{|c|}{ DNPP } & \\
\hline & & & $\mathrm{MgCl}_{2}$ & EDTA & \\
\hline $600 \mathrm{~g}$ & 116 & 85 & 42 & 40 & 19 \\
\hline $10,000 \mathrm{~g}$ & 126 & 110 & 80 & 74 & 35 \\
\hline $100,000 \mathrm{~g}$ & 1,240 & 620 & 198 & 175 & 115 \\
\hline Supernatant & 2,100 & 1,130 & 210 & 210 & 155 \\
\hline
\end{tabular}

DNPP was used as the substrate for PPDase activity, the hydrolytic activity for DNPP was not depressed by the addition of EDTA.

Basic Properties of PPDase in the Microsomal Fraction.

By using the microsomal fraction, several basic properties of PPDase activity were examined. The time course of the reaction is shown in Fig. 1. The reaction almost proceeded linearly for one hour.

As shown in Fig. 2, the hydrolysis of DNPP was proportional to the amount of added microsomal fraction. When oligo DNA was used as the substrate, the proportionality was obtained between PPDase activity and the amount of enzyme in a range of concentration of enzyme less than $0.2 \mathrm{ml}$, with the addition of magnesium chloride, but it was not observed with the addition of EDTA. This fact might be attributed to the changes of physical state of microsomes.

As shown in Fig. 3, pH activity curve gave the broad peak at $\mathrm{pH} 6.0$ for DNPP but sharp peak at the same $\mathrm{pH}$ for oligo DNA. In the latter case, the $\mathrm{pH}$ activity curves in different buffer systems were not connected smoothly, and such a phenomenon might be caused by the activation of the enzyme by the existence of Tris. or imidazole. The similar results were observed in a study of RNase reported previously ${ }^{1)}$.

Effect of Metal Ions.

The effect of metal ions on PPDase activity 


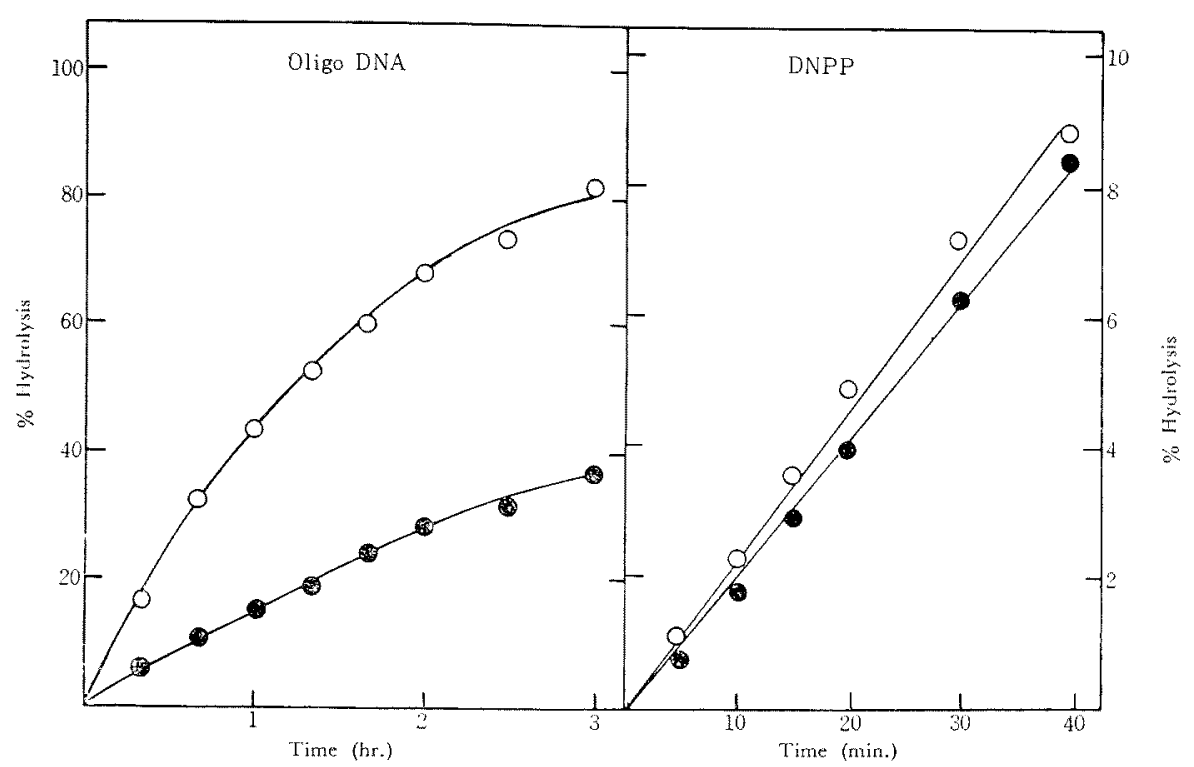

FIG. 1. Time Course of the Reaction.

The microsomal suspension was used as the enzyme; $390 \mu y$ of protein per ml was used for oligo DNA as the substrate, $250 \mathrm{\mu g}$ of protein per $\mathrm{ml}$ for DNPP.

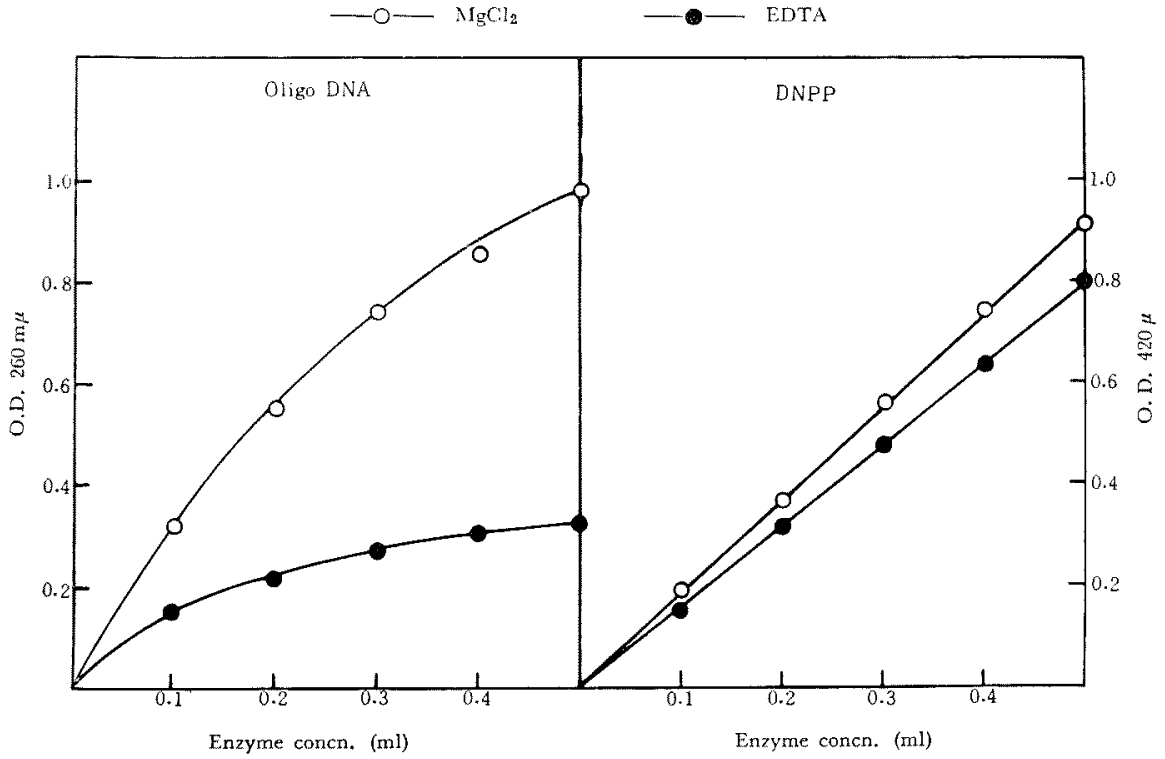

FIG. 2. Relationship Between the Activity and Enzyme Concentration.

Microsomal suspension was used as the enzyme; $1,530 \mu \mathrm{g}$ of protein per ml was used for oligo DNA as the substrate, $380 \mu \mathrm{g}$ of protein per $\mathrm{ml}$ was used for DNPP.

$$
-\mathrm{O}-\mathrm{MgCl}_{2}
$$

of the microsomal fraction was investigated by using oligo DNA as the substrate. The results are shown in Table III. In addition to magnesium ion, calcium, cobalt, manga- 


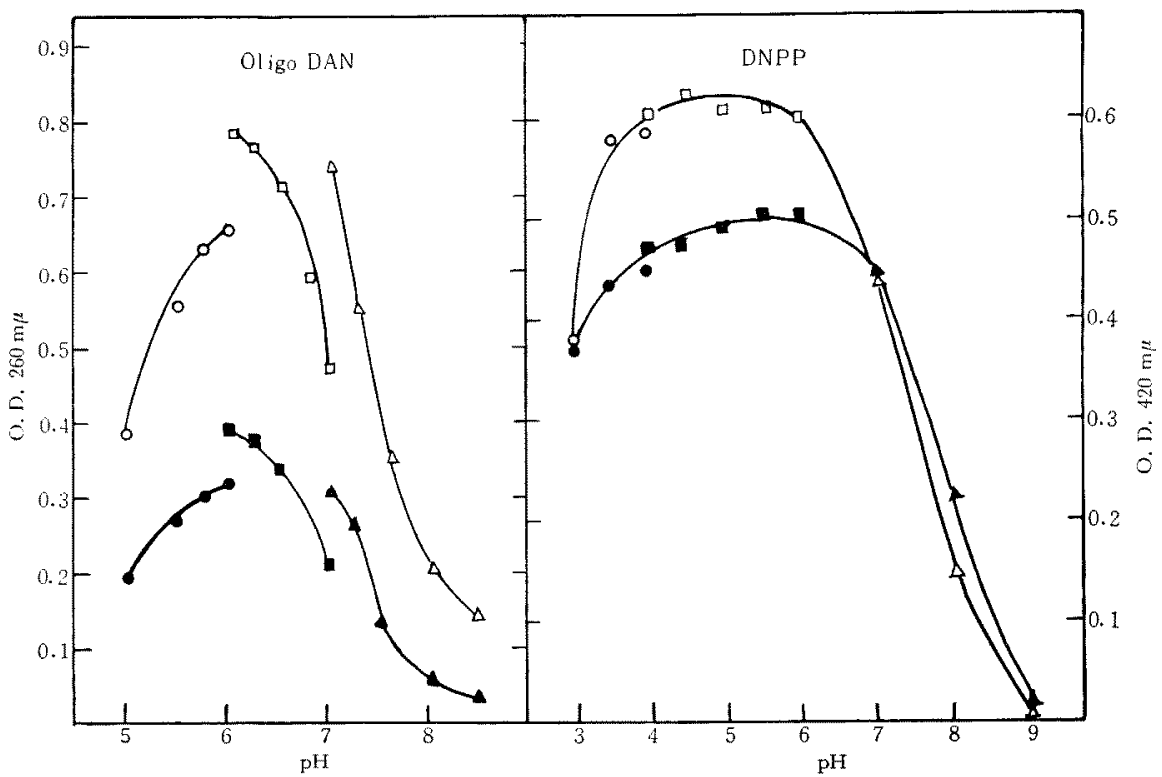

FIG. 3. Effect of $\mathrm{pH}$ on Enzyme Activity.

Left: Circles, Acetate; Squarcs, Imidazole-HCI ; Triangles, Tris-HCl.

Right: Circles, Glycien-HCl; Squares, Acetate; Triangles, Tris.-HCl.

Open symbols designate the activities in the presence of $\mathrm{MgCl}_{2}$ and solid symbols, EDTA. $380 \mu g$ of protein per ml was used for oligo DNA as the substrate, $120 \mu \mathrm{g}$ of protein per mal for DNPP.

TABle III. EFFect of MEtal IONS ON PHOSPHODIESTERASE ACTIVITY

$\begin{array}{ccc}\text { Metal } & \begin{array}{c}\text { Concentration } \\ (\mathrm{M})\end{array} & \text { Relative activity } \\ \mathrm{MgCl}_{2} & 10^{-2} & 100 \\ \prime \prime & 5 \times 10^{-3} & 60 \\ \prime \prime & 10^{-3} & 49 \\ \mathrm{CaCl}_{2} & 10^{-2} & 103 \\ \prime \prime & 10^{-3} & 50 \\ \mathrm{CoCl}_{2} & 10^{-2} & 130 \\ \prime \prime & 10^{-3} & 65 \\ \mathrm{MnCl}_{2} & 10^{-2} & 106 \\ \prime \prime & 10^{-3} & 45 \\ \mathrm{NiCl} 2 & 10^{-2} & 117 \\ \prime \prime & 10^{-3} & 75 \\ \mathrm{KCl} & 2 \times 10^{-2} & 41 \\ \text { EDTA } & 10^{-2} & 48 \\ \text { None } & - & 43\end{array}$

Oligo DNA was used as the substrate, and the microsonal fraction as the enzyme.

nese and nickel ions were effective on PPDase activity in the concentration of $10^{-2} \mathrm{M}$. From the results, the effect of magnesium or cal- cium ion contained in oligo DNA or DNPP preparation in order of $10^{-4} \mathrm{M}$ seemed to be negligibly small.

Hydrolytic Products of RNA by the Microsomal Fraction.

In the preceding paper $^{6)}$, alkaline region was used as the reaction medium according to the general concept of PPDase. Since it was proved that the $\mathrm{pH}$ optimum of the PPDase activity in wheat seedlings existed in acidic region, yeast RNA was allowed to react with the microsomal fraction at $\mathrm{pH} 6.9$ taking the effect of Tris. into consideration which was described above. That is, the reaction mixture, total volume of $40 \mathrm{ml}$, containing $200 \mathrm{mg}$ of yeast RNA, $400 \mu$ moles of magnesium chloride, 4 mmoles of Tris-hydrochloride ( $\mathrm{pH} 6.9$ ) and $15 \mathrm{mg}$ of microsomal fraction was incubated at $50^{\circ} \mathrm{C}$ for three hours with continuous stirring. After the reaction had been stopped by the addition 


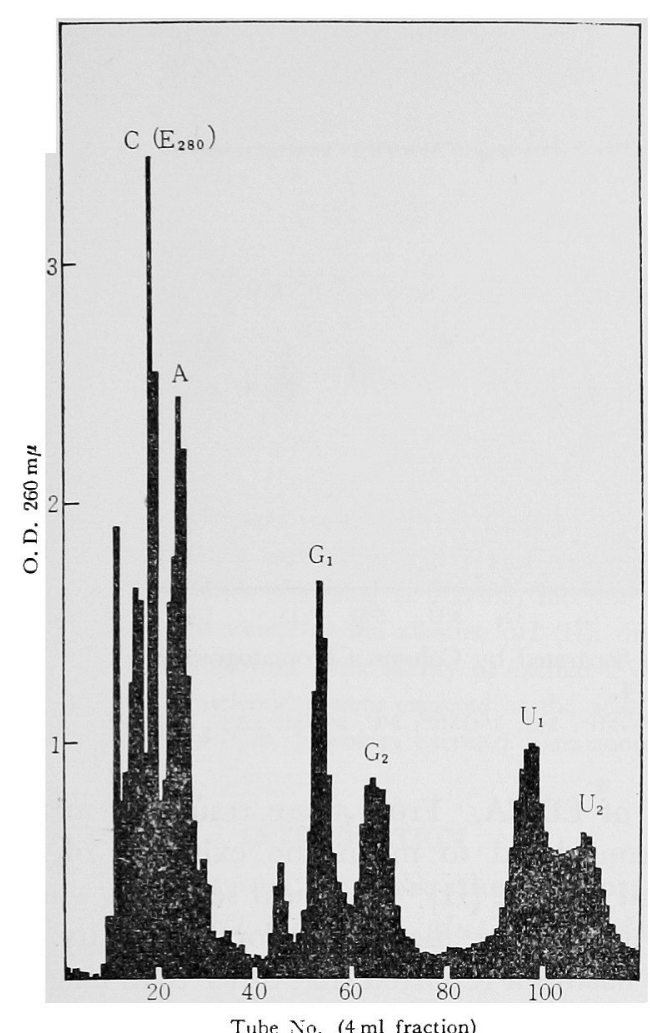

FIG. 4. Column Chromatogram of the Nucleotides Prepared from the Hydrolysate of RNA by the Microsomal Fraction.

of uranyl reagent, the acid soluble fraction was obtained by filtration. A part of the neutralized acid soluble fraction was applied on a column, washed with water and eluted by formic acid in order to separate nucleotides. The column chromatogram is shown in Fig. 4. From the spectrophotometric data of the peaks, each fraction was considered to be composed of mononucleotide. The fractions designated as $C, A, G_{1}, G_{2}$, and $U_{1}$ and $\mathrm{U}_{2}$ were dried in vacuo, dissolved in a small amount of dilute ammonium solution, and then identified by using the thin layer chromatography. The results are shown in Fig. 5. The peaks of $\mathrm{C}, \mathrm{A}, \mathrm{G}_{1}, \mathrm{G}_{2}, \mathrm{U}_{1}$ and $\mathrm{U}_{2}$ were identified as $5^{\prime}$-CMP, the mixture of $5^{\prime}$ - and $3^{\prime}$-AMP, 5'-GMP, 3'-GMP, 5'-UMP and 3'-UMP, respectively. Furthermore, the fractions detected as $5^{\prime}$-nucleotides were tested with periodate Schiff reagent ${ }^{16}$ They all showed positive results. From these results, it may be considered that RNA were hydrolyzed into 5'-nucleotides by PPDase [I] and into 3'-nucleotides by RNase besides so-called PPDase [II] (see discussion) which were present in the microsomal fraction together.

In the fractions of $\mathrm{C}$ and $\mathrm{A}, 3^{\prime}$-nucleoticles were found to be less than $5^{\prime}$-nucleotides. As one of the cause of these facts, the partial hydrolysis of nucleotides by the nucleotidases contained in the microsomal fraction ${ }^{2)}$. is conceivable. It was not investigated whether oligonucleotides, cyclic nucleotides and nucleoside diphosphates etc. were formed, or not.

\section{DISCUSSION}

PPDase in venom and microorganisms have been studied extensively ${ }^{17,18)} \quad$ But the studies on PPDase in plants are comparatively $\mathrm{few}^{9,19 \sim 21 \text { ) }}$

This paper confirmed that a PPDase which produced 5'-nucleotides from RNA occurred in wheat roots. The $\mathrm{pH}$ optimum of this enzyme was in acidic region whereas the $\mathrm{pH}$ optimum of PPDases which produce 5'-nucleotides in venom or microorganisms were generally found in alkaline region except a few cases $^{22}$ It was reported that, however, the $\mathrm{pH}$ optimum of PPDase in barley was 6.0 by Chargaff( ${ }^{9}$ and that of a nuclease in mung bean was 6.0 by Laskowski ${ }^{21)}$. When DNPP was used as the substrate for PPDase

\footnotetext{
16) Z. Sugimoto, K. Iwasa, J. Ishiyama and T. Yokozuka, Nippon Nogeikagaku Kaishi (in Japanese), 36, 277 (1962).

17) H.G. Khorana, "The Enzymes" Vol. 5, Ed. P.D. Boyer, H. Lardy and K. Myrbäck, Acad. Press, 1961, p. 79.

18) K. Ogata, Kagaku to Soibutsu, 1, 11 (1962).

19) L. Shuster, J. Biol. Chem., 229, 289 (1957).

20) L. Shuster, Biochim. Biophys. Acla, 33, 452 (1959).

21) S. Sung and M. Laskowski, J. Biol. Chem., 237, 506 (1962).

22) A. Kuninaka, M. Kibi, H. Yoshino and K. Sakaguchi, This Journal, 25, 693 (1961).
} 


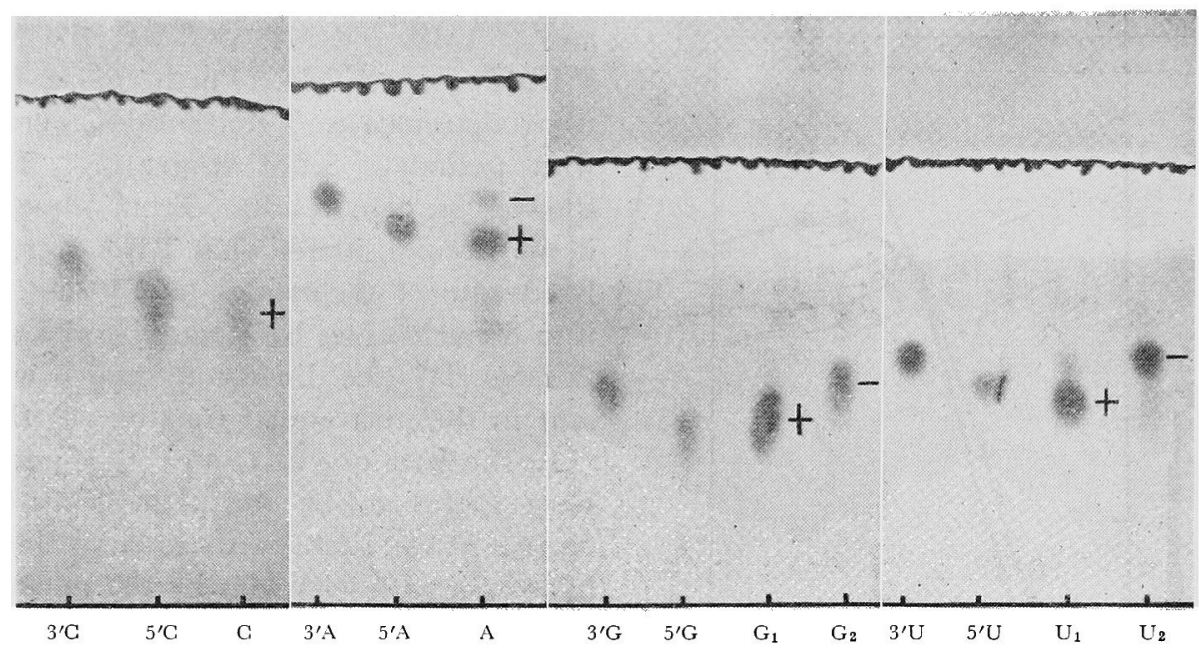

FIG. 5. Thin Layer Chromatogram of the Nucleotides Separated by Column Chromatography as Shown in Fig. 4.

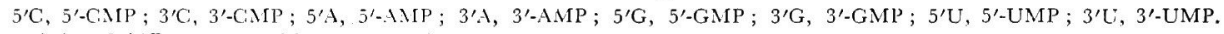
+ ; periodate Schiff reagent positive, - ; nezative.

activity, there was no difference between the activities obtained with addition of magnesium chloride and with EDTA. From the results, it may be considered that DNPP does not require metal ions for its enzymatic degradation. It has been reported that DNPP is a rather poor substrate for venom PPDase ${ }^{23)}$, and that the $\mathrm{pH}$ optimum for DNPP was found in acidic region even in the case that the $\mathrm{pH}$ optimum of PPDase for RNA or DNA was found in alkaline region ${ }^{24)}$. These results may be due to the difference between natural substrate and synthetic one. A considerable hydrolytic activity of PPDase for oligo DNA was obtained even in the addi-

23) W.E. Razzell and H.G: Khorana, J. Biol. Chem., 234, 2105 (1959).

24) M. Nakai, Z. Minami, T. Yamazaki, A. Tsugita and Y. Hirota, Presented at 15th Meeting of Symposium on Enzyme Chemistry in Osaka (May, 1963). tion of EDTA. From these results, it might be considered to mean the existence of socalled PPDase $[\mathrm{II}]^{25)}$ in wheat seedlings which did not require metal ions for its activity. ...

It has been reported that other than magnesium ion, cobalt, manganese, strontium, zinc and calcium ions were effective on the activity of $\mathrm{DNase}{ }^{26)}$, but various divalent cations were not effective on venom PPDase activity ${ }^{23}$. However, present paper showed that divalent cations were effective on PPDase in wheat seedlings.

The fact that PPDase occurs in wheat seedlings, especially in the microsomal fraction, may be interesting on consideration of the nucleic acid metabolism and protein biosynthesis.

25) W.E. Razzell, J. Biol. Chem., 236, 3028 (1961).

26) J.L. Potter and M. Laskowski, ibid., 234, 1263 (1959). 